\title{
Pineal Region Germinoma
}

National Cancer Institute

\section{Source}

National Cancer Institute. Pineal Region Germinoma. NCI Thesaurus. Code C8712.

A germinoma that arises from the pineal gland. 